\title{
PELAKSANAAN PENYIMPANAN FAMILY FOLDER TERHADAP EFEKTIVITAS PENYIMPANAN BERKAS REKAM MEDIS DI PUSKESMAS CIKARO
}

\author{
Rizka Fujiawanti ${ }^{1}$, Defi Eka Novianty ${ }^{2}$, Erix Gunawan ${ }^{3}$ \\ Politeknik Piksi Ganesha Bandung, Indonesia ${ }^{1,2,3}$ \\ Piksi.defi.18303179@gmail.com¹, Piksi.rizka.18303180@gmail.com², \\ erix.gunawan@piksi.ac.id ${ }^{3}$
}

Received: 11-07-2021

Revised : 17-11-2021

Accepted: 18-11-2021

\begin{abstract}
Abstrak
Latar Belakang: Bentuk sistem penomoran dan penyimpanan yang baik merupakan tahap awal dalam pemberian pelayanan terhadap pasien. Pengambilan dan penyimpanan rekam medis yang cepat merupakan elemen penting dalam pemberian pelayanan. Perlu kehati-hatian dalam merencanakan sistem penomoran dan penyimpanan.

Tujuan: Tujuan penelitian ini adalah menganalisis pelaksanaan penyimpanan berkas rekam medis menggunakan penomoran family folder di Puskesmas Cikaro.

Metode: Jenis penelitian yang digunakan adalah praktik kerja lapangan yang bersifat deskriptif, dengan pendekatan kualitatif dan kuantitatif. Subjek penelitian adalah 4 orang karyawan di Instalasi Rekam medis. Objek penelitian adalah aplikasi simpus yang digunakan di pendaftaran, Standar operasional prosedur dan ruang penyimpanan berkas rekam medis.
\end{abstract}

Hasil: Hasil penelitian menunjukan adanya nomor rekam medis yang ganda, terdapat Missfile dan banyak map rekam medis yang disimpan tidak sesuai dengan penjajaran yang ada.

Kesimpulan: Berdasarkan hasil penelitian dan pembahasan yang telah diuraikan, maka peneliti menyimpulkan petugas rekam medis di Puskesmas Cikaro sudah ada yang berkualifikasi pendidikan perekam medis dan informasi kesehatan.

Kata kunci: rekam medis; penomoran; penyimpanan.

\begin{abstract}
Background: The form of a good numbering and storage system is the initial stage in providing services to patients. Quick retrieval and storage of medical records is an important element in service delivery. Care needs to be taken in planning the numbering and storage system

Objective: The purpose of this study was to analyze the implementation of medical record file storage using family folder numbering at Cikaro Health Center.
\end{abstract}




Methods: The type of research used is descriptive field work
practice, with qualitative and quantitative approaches. The
research subjects were 4 employees at the Medical Record
Installation. The object of research is the Simpus
application used for registration, standard operating
procedures and medical record file storage space.
Results: The results showed that there were double medical
record numbers, there were Miss files and many medical
record folders that were stored did not match the existing
alignment.
Conclusion: Based on the results of the research and
discussion that has been described, the researchers
conclude that there are already medical record officers at
the Cikaro Health Center who have medical record and
health information qualifications.
Keywords: medical record; numbering; storage.
*Correspondent Author: Rizka Fujiawanti
Email: Piksi.defi.18303179@ gmail.com
(i) (O)

\section{PENDAHULUAN}

Pusat Kesehatan Masyarakat adalah fasilitas pelayanan kesehatan tingkat pertama yang menyelenggarakan upaya kesehatan masyarakat dan upaya kesehatan perseorangan, dengan mengutamakan upaya promotif dan preventif, untuk mencapai derajat kesehatan masyarakat yang setinggi-tingginya di wilayah kerjanya (Permenkes, 2014). Puskesmas adalah unit pelaksana teknis dinas kabupaten/kota yang memiliki tanggung jawab untuk menyelenggarakan pembangunan kesehatan di suatu wilayah kerja (Harianja, 2018).

Berdasarkan survei awal di Puskesmas Cikaro diketahui bahwa pelayanan rekam medis di Puskesmas dimulai dari pendaftaran pasien, pelayanan medis rawat jalan, pelayanan administrasi keuangan, pelayanan pencatatan, pelaporan dan penyimpanan (Marlina, 2014). Bagian sistem tersebut terdapat sub sistem rekam medis yang terdiri dari sistem penomoran, sistem penyimpanan dan sistem penjajaran (Hatta, 2013). Hal lain yang juga penting, yang mendasari pemikiran dalam (Nomor, 2017) bahwa keperluan peraturan tersebut mendesak, adalah peran rekam medis sebagai suatu berkas alat bukti tertulis yang sah dalam pembuktian masalah-masalah hukum, etik dan disiplin. Peran fungsi ini dengan jelas disebutkan sebagai salah satu manfaat dari rekam medis dalam Permenkes Nomor 269/MENKES/PER/III/2008 tentang Rekam Medis.

Sistem penomoran tujuan nya untuk memudahkan pencarian dokumen rekam medis apabila pasien kemudian datang kembali berobat di sarana-sarana pelayanan kesehatan serta untuk kesinambungan informasi dengan menggunakan sistem penomoran maka informasi-informasi dapat secara berurut dan meminimalkan informasi yang hilang (Rumana, 2019).

Sistem penyimpanan yang digunakan di Puskesmas Cikaro adalah Family numbering atau family folder, merupakan sistem penyimpanan yang paling tepat untuk FKTP dimana semua anggota keluarga dapat menerima perawatan kesehatan dengan sistem ini satu nomor unit diberikan untuk 1 rumah tangga dan ekstra digit ditambahkan untuk menunjukkan setiap individu dalam rumah tangga (keluarga). Contoh: $1=$ kepala rumah tangga (ayah) 2 =istri (ibu) $3=$ anak/keluarga yang lain (Simanjuntak, 2021).

Berdasarkan studi pendahuluan dan pengalaman praktik lapangan pada semester 6 yang peneliti lakukan di Puskesmas Cikaro peneliti melihat pengelolaan rekam medis nya Pelaksanaan Penyimpanan Family folder Terhadap Efektivitas Penyimpanan Berkas Rekam Medis di Puskesmas Cikaro 
cukup baik, akan tetapi ada beberapa permasalahan yaitu dokumen rekam medis yang disimpan di rak penyimpanan terlalu banyak atau padat sehingga cukup sulit untuk mengambil berkas maupun menyimpan berkas di rak tersebut. Di samping itu peneliti menemukan berkas rekam medis dengan nomor yang sama tetapi beda keluarga (nomor ganda) sehingga sering terjadi missfile atau salah memberikan berkas.

\section{METODE PENELITIAN}

Jenis penelitian yang digunakan yaitu penelitan dengan metode deskriptif dengan pendekatan kualitatif dan Kuantitatif (Moleong, 2017). Penelitian ini dilakukan di Puskesmas Cikaro yang beralamat di Jl. Kesehatan No. 03 Rt 03 Desa Majakerta Kecamatan Majalaya Kabupaten Bandung. Pada tanggal 20 April 2021 sampai dengan 20 Juni 2021. Subjek penelitian pada penelitian ini adalah petugas rekam medis, sistem penyimpanan rekam medis, prosedur penyimpanan rekam medis, dan fasilitas penyimpanan rekam medis. Adapun jumlah Informan dalam penelitian ini adalah 4 orang petugas rekam medis, diantaranya kepala rekam medis sebanyak 1 orang dan petugas pelaksana sebanyak 3 orang. Analisis penelitian yang digunakan adalah analisis data yang dilakukan dengan cara deskriptif, penyajian dan penarikan kesimpulan, sehingga diperoleh gambaran yang jelas tentang pelaksanaan penyimpanan berkas rekam medis family folder di Puskesmas Cikaro. Data primer diperoleh langsung dari petugas rekam medis melalui wawancara dan dari hasil praktek kerja lapangan. Data sekunder adalah data yang sudah ada yaitu profil Puskesmas, kebijakan dan SOP yang ada di Puskesmas, penelitian sebelumnya serta dokumentasi lainnya.

\section{HASIL DAN PEMBAHASAN}

\section{A. Hasil Penelitian}

\section{Karakteristik Informan}

Tabel 1. Karakteristik Informan

\begin{tabular}{clll}
\hline Petugas Rekam Medis & Jenis Kelamin & \multicolumn{1}{c}{ Pendidikan } & Lama Kerja \\
\hline Informan 1 & Perempuan & SMA & 33 Tahun \\
\hline Informan 2 & Perempuan & DIII-REKAM MEDIS & 4 Tahun \\
\hline Informan 3 & Perempuan & SMA & 3 Tahun \\
\hline Informan 4 & Laki-Laki & SMA & 2 Tahun \\
\hline
\end{tabular}

Berdasarkan tabel 1 di atas, informan 1 berjenis kelamin perempuan berumur 56 tahun dengan tingkat pendidikan SMA dimana lama kerjanya 33 tahun. Informan 2 berjenis kelamin perempuan dan berumur 25 tahun dengan tingkat pendidikan D-III Rekam medis dimana lama kerjanya 4 tahun. Informan 3 berjenis kelamin perempuan berumur 24 tahun dengan tingkat pendidikan SMA dimana lama kerjanya 3 tahun. Informan 4 berjenis kelamin laki-laki berumur 32 tahun dengan tingkat pendidikan SMA dimana lama kerjan nya 2 tahun.

\section{Sistem Pendaftaran}

Tabel 2. Hasil Sistem Pendaftaran

No. Pengamatan $\quad$ Keterangan




\begin{tabular}{ll}
\hline Pendaftaran & Sebagai acuan penerapan Langkah- \\
& langkah untuk petugas Pendaftaran \\
& supaya tertib dalam melaksanakan \\
& kegiatan pendftaran demi kenyaman \\
& dalam pelayanan pasien \\
& dilingkungan puskesmas Cikaro. \\
\hline
\end{tabular}

Berdasarkan tabel 2 di atas, hasil penelitian di Puskesmas Cikaro sistem pendaftaran adalah awal dari pelaksanaan penyimpanan rekam medis yaitu suatu tempat pelayanan penerimaan pasien atau pelayanan rekam medis yang diberikan kepada pasien yang datang berobat ke instalasi rawat jalan.

\section{Sistem Penyimpanan Rekam Medis}

Tabel 3. Hasil Observasi Sistem Penyimpanan Rekam Medis

\begin{tabular}{|c|c|c|}
\hline No. & Pengamatan & Keterangan \\
\hline 1 & Penomoran & $\begin{array}{l}\text { Rekam medis di Puskesmas Cikaro menggunakan sistem } \\
\text { penomoran Numeric }\end{array}$ \\
\hline 2 & Penjajaran & $\begin{array}{l}\text { Rekam medis di Puskesmas Cikaro Menggunakan sistem } \\
\text { Straight Numerical Filing yang mana berkas rekam medis } \\
\text { dijajarkan berdasarkan urutan langsung nomor rekam } \\
\text { medisnya pada rak penyimpanan. }\end{array}$ \\
\hline 3 & Sistem Penyimpanan & $\begin{array}{l}\text { Sistem penyimpanan menggunakan Family folder yaitu } \\
\text { satu berkas rekam medis digunakan oleh satu keluarga dan } \\
\text { terdapat kode tambahan khusus untuk ayah } 01 \text { ibu } 02 \text { anak } \\
\text { ke-1 } 03 \text { dan seterusnya. Menggunakan penyimpanan sesuai } \\
\text { lokasi yaitu sentralisasi, yang mana berkas rekam medis } \\
\text { disimpan dalam satu ruangan. }\end{array}$ \\
\hline
\end{tabular}

Berdasarkan tabel 3 di atas, hasil observasi penyimpanan rekam medis di Puskesmas Cikaro menggunakan sistem penyimpanan Family folder, dikelola secara Sentralisasi menggunakan sistem penjajaran Straight Numerical Filing (SNF) serta menggunakan kode wilayah, penomoran berkas rekam medis menggunakan Numeric.

\section{Sistem Pengambilan Berkas Rekam Medis}

Tabel 4. Hasil Observasi Pengambilan Berkas Rekam Medis

\begin{tabular}{cll}
\hline No. & \multicolumn{1}{c}{ Pengamatan } & \multicolumn{1}{c}{ Keterangan } \\
\hline 1 & Pengambilan rekam medis & Pengambilan rekam medis dilakukan pada \\
& dilakukan oleh petugas rekam medis & saat diakhir jam kerja, sehingga \\
& dan dilakukan sudah sesuai prosedur & penyimpanan rekam medis dapat langsung \\
& SOP. & dilakukan setelah akhir jam kerja. \\
\hline
\end{tabular}

Berdasarkan tabel 4 di atas, hasil observasi yang dilakukan oleh peneliti menunjukan bahwa pengambilan dan penyimpanan berkas rekam medis di ruang penyimpanan hanya dilakukan petugas rekam medis dan dilakukan sudah sesuai dengan prosedur di akhir jam kerja.

\section{Sistem Pengembalian Berkas Rekam Medis}

Tabel 5. Hasil Observasi Sistem Pengembalian Berkas Rekam Medis

No. Pengamatan $\quad$ Keterangan

Pelaksanaan Penyimpanan Family folder Terhadap Efektivitas Penyimpanan Berkas Rekam Medis di Puskesmas Cikaro 
$1 \quad$ Pengembalian berkas dilakukan $\quad$ Kadang berkas rekam medis dikembalikan selain petugas rekam medis oleh perawat dari poli.

Berdasarkan tabel 5 di atas, hasil observasi yang dilakukan oleh peneliti menunjukan bahwa pengembalian rekam medis bisa dilakukan selain oleh petugas rekam medis.

\section{Fasilitas Penyimpanan Berkas Rekam Medis}

Tabel 6. Hasil Observasi Fasilitas Penyimpanan Berkas Rekam Medis

\begin{tabular}{llccl}
\hline No. & Observasi & Ya & Tidak & \multicolumn{1}{c}{ Keterangan } \\
\hline 1 & Tracer & & $\checkmark$ & Tidak menggunaka tracer \\
\hline 2 & Buku Ekspedisi & & $\checkmark$ & Tidak menggunakan Buku Ekpedisi \\
\hline 3 & Map Rekam Medis & $\checkmark$ & & Menggunakan Map \\
\hline 4 & Tangga & & $\checkmark$ & Tidak Menggunakan tangga \\
\hline 5 & Rak Penyimpanan & $\checkmark$ & & Menggunakan Rak penyimpanan \\
\hline
\end{tabular}

Berdasarkan tabel 6 di atas, hasil observasi bahwa di ruang penyimpanan terdapat map berkas RM, rak penyimpan sedangkan tangga, tracer dan buku ekspedisi tidak tersedia.

\section{B. Pembahasan}

\section{Karakteristik Informan}

Berdasarkan hasil penelitian sebagian besar dalam kategori umur $<35$ tahun sebanyak 3 orang dan sisanya 1 orang berumur $>35$ tahun. Berdasarkan jenis kelamin sebagian besar berjenis kelamin perempuan yaitu sebanyak 3 orang dan 1 orang berjenis kelamin laki-laki. Berdasarkan dari pendidikan hanya 1 orang yang pendidikannya berlatar belakang D-III Rekam Medis, 1 orang PNS (Pegawai Negeri Sipil) dan 2 orang lain nya lulusan dari SMA. Hal ini mengakibatkan kurangnya pengetahuan petugas dalam penyimpanan, karena dari aspek kompetensi tidak memenuhi syarat standar pengengetuhan kompetensi perekam medis.

\section{Kebaruan Penelitian}

Sudah banyak penelitian yang mengkaji tentang Tata Pelaksanaan Penyimpan Rekam Medis, Namun masig masing daerah tentu memiliki karakteristik tersendiri untuk tema tersebut. Baik dari penyebab terjadinya kolaborasi, siapa saja yang terlibat, tahapan yang dilalui selama berkolaborasi, hambatan yang dilalui, dan kewenangan masing masing pihak yang terlibat. Selain itu fokus masalah yang di kaji yakni terkait Tata Pelaksaanan Penyimpanan. Dalam sebuah forum belum banyak dilakukan oleh penekiti terdahulu.

\section{Pelaksanaan Penyimpanan Berkas Rekam Medis}

Berdasarkan hasil penelitian menunjukan bahwa terdapat Standar Operasional (SOP) di mulai dari pendaftaran, penyimpanan, penomoran, monitoring kelengkapan dan kerahasiaan rekam medis. Sesuai dengan hasil observasi dan wawancara penyimpanan berkas Rekam Medis di Puskesmas Cikaro menggunakan sistem penyimpanan Family folder, dikelola secara Sentralisasi menggunakan sistem penjajaran Straight Numerical Filing (SNF) serta menggunakan kode wilayah, penomoran menggunakan Numeric.

Pelaksanaan penyimpanan maupun alur sudah tertulis dengan lengkap dan sudah dilaksanakan cukup baik, hanya pelaksanaan nya masih ada yang tidak sesuai SOP yaitu ditemukan double rekam medis 1 nomor rekam medis dimiliki oleh 2 orang dari kepala keluarga yang berbeda, hal ini terjadi karena sistem informasi puskesmas (simpus) sering 
terjadi kendala jaringan, sehingga tidak bisa melacak nomor rekam medis lama dan berakibat pasien tersebut diberikan nomor yang baru.

\section{Pengambilan Berkas Rekam Medis}

Berdasarkan hasil penelitan menunjukan bahwa pengambilan berkas rekam medis dilakukan oleh petugas pendaftaran, karena memang sedikit nya petugas rekam medis mengakibatkan tidak ada nya pembagian petugas, dan pengerjaanya dilakukan di akhir jam kerja.

\section{Sistem Pengembalian Berkas Rekam Medis}

Berdasarkan hasil penelitian menunjukan bahwa pengembalian berkas rekam medis dilakukan setelah jam kerja. Hanya saja peneliti menemukan berkas yang tidak ada di rak penyimpanan dan masih belum dikembalikan dari poli. Sesuai dengan teori (Riyanto, 2012) pada peminjam semestinya membuat ketentuan berapa jangka lama waktu untuk 1 rekam medis di ijinkan tidak terdapat pada rak penyimpanan. Semestinya setiap dokumen rekam medis kembali pada setiap akhir hari kerja.

Pengembalian yang tidak sesuai dengan ketentuan dapat mengakibatkan miss file pada sistem penyimpanan, dan petugas filing pada keesokan harinya menjadi kewalahan karena harus menyusun berkas yang harus dikembalikan dan juga petugas harus mencari berkas pasien yang berobat saat itu, sehingga akan terjadi penumpukan pasien pada pendaftaran (Ritonga \& Lubis, 2021).

\section{Fasilitas Penyimpanan Berkas Rekam medis}

Sesuai penelitian dan wawancara fasilitas pada ruang penyimpanan dijumpai rak dan map rekam medis sedangkan tangga, tracer dan buku ekspedisi belum ada, hal ini tidak sesuai dengan teori pengambilan berkas (Suraja, 2019) yang berakibat missfile karena petugas tidak tahu keberadaan rekam medis setelah digunakan untuk pelayanan. Disamping itu tidak adanya sirkulasi udara dan pendingin ruangan sehingga ruangan menjadi lembab dan terasa pengap. Tidak adanya ruangan khusus untuk retensi sehingga tidak terlaksana nya pemusnahan berkas sesuai dengan tahun kunjungan sehingga berkas menjadi bertumpuk dibagian filing.

Bagian Kartu Berobat itu tercantum No File, Nama Kepala Keluarga/KK, No Rekam Medis pasien, alamat dan baris untuk beberapa keluarga yang datang untuk berobat lagi. Biasanya pasien yang sudah pernah berobat lalu kedatangan berikutnya oleh anggota keluarga lainnya itu akan dijadikan satu Nomor File tetapi berbeda nomor rekam medis, map untuk keduanya pun dibedakan karena khawatir jika mereka bersama-sama berobat lalu berbeda poli itu akan cukup memakan waktu yang sangat banyak, oleh sebab itu, penggunaan family folder pun dihapuskan oleh Puskesmas karena banyak menyita waktu terlebih banyak kasus pasien berobat bersama-sama satu keluarga tetapi beda poli (Nurussyifa, Penti, \& Sari, 2021).

\section{KESIMPULAN}

Berdasarkan hasil penelitian dan pembahasan yang telah diuraikan, maka peneliti menyimpulkan petugas Rekam Medis di Puskesmas Cikaro sudah ada yang berkualifikasi pendidikan Perekam Medis dan Informasi Kesehatan. Sistem penyimpanan yang dilakukan pada Puskesmas Cikaro menggunakan family folder, dan penjajaran menggunakan Straight Numerical Filing (SNF). Pelaksanaan prosedur penyimpanan sudah sesuai dengan SOP yang ada dan dilindungi dari akses yang tidak berhak atau selain petugas rekam medis. Prosedur pengembalian rekam medis selalu dipulangkan pada akhir jam kerja. Fasilitas dan sarana yang ada di ruang penyimpanan di puskesmas cikaro kurang memadai, untuk 
kelengkapan dan tempatnya, yaitu tidak adanya tangga, tracer, dan buku ekspedisi serta kurang nya sirkulasi udara dan pendingin ruangan.

\section{BIBLIOGRAFI}

Harianja, Harianja. (2018). Perancangan Aplikasi Rawat Jalan Pada Unit Pelaksana Teknis Dinas (UPTD) Kesehatan Benai. Jurnal Teknologi Dan Open Source, 1(1), 8-24.

Hatta, Gemala R. (2013). Pedoman Manajemen Informasi Kesehatan Disarana Pelayanan Kesehatan (Revisi 2). Jakarta: Universitas Indonesia.

Marlina, Evi. (2014). Tinjauan Pelayanan Rekam Medis Bagian Filing di Puskesmas Bejen Kabupaten Temanggung Tahun 2014. Eprints. Dinus. Ac. Id.

Moleong, Lexy J. (2017). Metodologi Penelitian Kualitatif (Bandung: Remaja Rosdakarya, 2013). Munawir, Ahmad Warson, Kamus Al-Munawir.

Nomor, Permenkes Republik Indonesia. (2017). 269/Menkes/Per III 2008 tentang Rekam Medis.

Nurussyifa, Adinda Amalia, Penti, Nisa Sri, \& Sari, Irda. (2021). Penerapan Nomor File dalam Manajemen Operasional Rekam Medis Berdasarkan Wilayah di Puskesmas Muka. Cerdika: Jurnal Ilmiah Indonesia, 1(10), 1255-1261.

Permenkes, R. I. (2014). Peraturan Menteri Kesehatan Republik Indonesia Nomor 75 tahun 2014, tentang Pusat Kesehatan Masyarakat. Jakarta: Menteri Kesehatan Republik Indonesia, 3-23.

Ritonga, Zulham Andi, \& Lubis, Hasran Ependi. (2021). Tinjauan Pelaksanaan Sistem Penyimpanan Rekam Medis Berdasarkan Standar Akreditasi Di UPTD Puskesmas Kotanopan Mandailing Natal. Jurnal Ilmiah Perekam Dan Informasi Kesehatan Imelda (JIPIKI), 6(1), 14-22.

Riyanto, B. (2012). Tinjauan Pelaksanaan Penyimpanan dan Pengambilan Dokumen Rekam Medis di Bagian Filling RSUD Kabupaten Karang Anyar. E-Jurnal Stikesmhk. Ac. Id.

Rumana, Nanda Aula, Widjaya, Lily, Indawati, Laela, Sitoayu, Laras, \& Angeliana, Devi. (2019). Revitalisasi Sistem Pengelolaan Rekam Medis di Klinik Khalifah Kabupaten Tangerang Tahun 2019.

Simanjuntak, Esraida. (2021). Penyuluhan Sistem Penyimpanan Rekam Medis di Puskesmas Glugur Darat Kota Medan. Ji-SOMBA, 1(1), 10-13.

Suraja, Yohannes. (2019). Pengelolaan Rekam Medis Pada Fasilitas Pelayanan Kesehatan. Jurnal Administrasi Dan Kesehatan, 4(1), 62-71.

(C) 2021 by the authors. Submitted for possible open access publication under the terms and conditions of the Creative Commons Attribution (CC BY SA) license (https://creativecommons.org/licenses/by-sa/4.0/). 